\title{
China's Strategic cooperation and Its interest position in the Middle East region
}

\author{
JAMAL AIT LAADAM* \\ School of International Public Affairs SIPA, Jilin University,2699, Changchun, P.R. China.
}

\begin{abstract}
:
Back to the creation of the China-Arab States Cooperation Forum (CASCF) in 2004, both sides have formed important political relations. Such a unique relationship, unlike from that of a military alliance, has strategic aspects of arrangement and has exceeded the common state-to-state interrelations in the globe. As Chinese leader $\mathrm{Xi}$ has addressed a series of important talks on the relationship between China and the Arab Middle East countries, which is of great significance in enriching the Middle East the development peace process and pushing forward China's relations with these countries, In his view of China's role in the Arab Middle East: "better looking for a friendship cooperation in the Middle East, we urge peace talks; better than pursuing any influence or hegemony, we call on all parties to engage in friendship cooperation sphere for one Belt and one Road Initiative; instead of undertaking to fill the gap, we create a cooperative partnership net for mutual win-win situation. Therefore, China's goal in the Arab world is to enlarge the gap of strategic partnership, in order to erase the influence of the "Islamic threat "and " Islamic phobia" not in Western media but in over the globe.
\end{abstract}

Keywords: Middle East. China Arab Countries. Diplomacy. Strategic cooperation. China relations

DOI: $10.7176 / \mathrm{IAGS} / 72-04$

Publication date:May $31^{\text {st }} 2019$

\section{Introduction :}

Back to the creation of the China-Arab States Cooperation Forum (CASCF) in 2004, both sides have formed special political relations. Such a special relationship, unlike from that of a military alliance, has strategic attributes of alignment and has exceeded the common state-to-state relations in the globe. Currently, Sino-Arab strategic cooperation will continue through a prosperous historical occasion. But, whether the Forum will forge to a formal organization such as the Shanghai Cooperation Organization (SCO) is reached by two competing aspects.

These significant aspects run from China and the Arab states sharing sets of shared values, focus on national dignity, political multi-polarity, diversity of development approaches and non-interference in each other's internal affairs; the negative aspects rest on Arab states having constitutional internal discords, low- level integration and different attitudes through the West, especially since the outbreak of the Arab uprisings. Indeed, to enhance strategic partnership and cooperation, China and Arab states should cease up the so-called "Islamic Threat phobia" to their perspective correspondence.

subsequent assumptions and hypothesis questioning the original root of Sino-Arab relations and how they shape their strategic partnership. So far, There has been some exchange consultations dialogue on the issue of ChineseArab strategic interrelations discourse between intellectuals, observers and academics. Basically, there's a strong foundation has been disposed of for Sino-Arab relation in the new approach, not only in term of strategic and security status, but also in economic, cultural, and political measures.

According to these measures, the recent 21 st century is the fruitful stage in Sino-Arab relations in the past decade. After the Cold War era, the Arab world has moved into a hazardous and unpredictable period of a political and social shift. Arab countries have got a high pressure from Western powers particularly the United States as well as from their internal public opinion on political transformation. In the doctrine of China's-Arab power politics, academics and intellectuals have improved many interpretations on the root of the ongoing SinoArab relations, including the so-called "new interrelation partnership", and "strategic partnership" the ongoing Sino-Arab partnership can be described as a strategic partnership, which is pointed out by $\{\mathrm{Li}, \mathrm{W}, 2005: 5\}$ in sense of expanding the continuity to do so in the following years.

Although there are three key outcomes for describing Sino-Arab relations in the new power politics approach as "strategic partnership": first of all, the core of China's rise is a mechanism of peaceful development. China upholds the existing international order rather than challenge it or change it. China's rise will give other states 
development freedom, especially third world countries. China's Silk-Road Strategy requires a westbound strategy, while the Arab states "looking-East" strategy has supplied an opportunity to create an intimate network with China. China and Arab states are likely to reach together peaceful development, as well as the recovery of Chinese and Islamic civilizations.

Secondly, China's peaceful development wants a balanced setting and the Arab world is a significant component of China's Great Periphery Diplomacy. Third, China and Arab states stake mutual outcomes and beneficial contribution in many fields, especially in trade and marketing business relations in the name of bilateral strategic partnership.

This is quite superficial with regards to new era of Sino-Arab cooperation, it breaks on three points: first, a shared simple traditional and comprehensive relationship, such as the historical ties of the "Ancient Silk Road "; second, the current exchange principles of win-win trade cooperation, like the economic interconnections; third, security and strategic outcomes of both parties (Wang, Y., 2008: 6-18), such as the geopolitical interconnections. With the soft extended development of China's economy, its dependence on foreign markets, raw materials, and oils resources will surely enhance Economic globalization has linked China with other states in the world economy: interdependence and win-win cooperation have described the state-tostate interrelations.

Under the so-called "comprehensive diplomacy", PRC has given up given first concern in its diplomatic relations to the Advanced Economies, like the United States, the European Union, Japan, Canada, and Australia. With its domestic market progressively watered, China has had to quest and enlarge foreign markets for its oversupplied commodities. The geographically-stage and encouraging markets from Central Asia to the West, and from North Africa to Central Africa, are significance progress. The CCP tries to build up closer political relations with Arab Maghreb states, in order to set up the foundations for their comprehensive partnership. Meantime, Arab states, like Saudi Arabia, the UAE, Algeria, Egypt, and North Sudan, have been effectively seeking strategic partnerships with China in recent years.

\section{China and Arab World: Strategic partnership and the political Attitude}

The political and economic partnership is the most significant engine for building solid strategic links between Beijing and Arab Maghreb states. Strong political relation networks will drive to good economic cooperation's; trade and financial relations between China and the Arab states constitute the benchmark of their political attitudes. Sovereign countries aim to have the incentive to boost economic and commercial trade relations with allies and strategic partners instead of with rivalries, because the benefits obtained by allies and partners will go to their military defense, becoming the public goods of the allies and partners as well (Gowa, J., 1995). Consequently, governments often employ various patterns of "political Influence Strategy" to minimize trade market and economic cooperation with their enemies and enlarge economic and trade exchanges with allies. For instance, in the post-Cold War era, China and the United States faced complicated issues on the RMB exchange rate, financial market access, trade deficit and another disagreement, which influenced somehow their unbeneficial political relations. In addition, China and the Arab countries sustained a good boost of development in economic and trade marketing relations, which is surely related to their favorable and appreciative political relations. In August 2010 China -Arab state trade has reached over \$190 billion, much larger than the US- Arab countries trade of 123 \$billion in the same year. According to Chinese Foreign Minister Yang Jiechi, both sides plan to bring to $\$ 300$ billion by the end of 2015. As its economic power keeps to grow, China is surely anticipated to expand and enlarge its political, economic and diplomatic influence in the Arab region.

Due to this depth strategic political cooperation, state-to-state interrelations can be practically divided into several stages: alliance, quasi-alliance, strategic partnership, traditional partnership. Although the Arab countries are divided instead of being unitary, Sino-Arab relations suit the stage of strategic partnership so far.

First of all, the alliance is a sort of interstate relations. By 20th century is also named as the "Era of alliances". In 1949 NATO was created to contain the Soviet Union; China and the Soviet Union signed the security pact in 1950 at least to counter other alliances (SEATO and CENTO). After years, later on, the creation of NATO the USSR set up the Warsaw Treaty Organization to counter NATO. The alliance strategy appeared as the keystone of the Cold War rivalry between the communist and the capitalist blocs (Rosenau, J. \& Thompson, K. \& Boyd, G., 1976: 371). The current academics in IR field point out that alliance is created only when the security matters in the form of a formal agreement, that is, the security engagement is endowed with legal force (Kegley, C. \& Raymond, G., 1990: 52). The kind of alliance is when two or more states sign up a formal agreement through a collection of military commitments to coordinate policies and strategies, in order to enhance their mutual 
security (Kegley, C. \& Wittkopf, E., 1999: 463). Hence, only security cooperation and commitments with formal military agreements can be described as "alliance".

Secondly, quasi-alliance is attached to the term alliance which stands of security cooperation between states on informal security agreements. The parties concerned in this constructive cooperation have not shaped a structure of comprehensive cooperation, even though they have an attitude for cooperation. Their cooperation often maintains in sort of non-sensitive fields with task-based respect, like anti-terrorism.

Third, quasi-alliance is displaced by the strategic cooperation which tends to form all forces to reach the target of the implementers. Policymakers should think not only the strategic outcomes, approaches, and other modes but also policy for complex decision-making actions. An effective strategy is a result of the comprehensive mechanism of the political leaders to advise the government and guarantee the flexibility of the political logic of several policy features. This logic highlights the perception of the government, that is, how to help the country's core interests and outcomes in the most effective way, based on the country's capability and capacity modes within the international framework (Jin, J., 2008: 22).

The strategic partnership is a political and security combination model based on interaction between two strategic states alliance, since the end of the Cold War which measures the following characteristics: first, it is a political combination between the main middle or global powers showing the fundamental role of major powers and their groups in the existing era. Second, it is often unclear and has an important significance, so that relations between states become more obscured, not easy to define. The sort of strategic cooperation between states usually leads to indicate the degree of intimacy of bilateral relations. For instance, from a logical point of view, there are some delicate differences between China's partnership with the United States, Russia, Japan, India, Pakistan, and the Arab countries. Third, strategic partnership forms a difficult link of relationships, so that almost all the major states follow usefulness to the strategic position of the other strong powers. It makes that partnership has become a useful asset, instead of a probability and liability. Therefore, political leaders think that the more partnerships you've got, the more and plenty of strategic resources they possess. Fourth, it is closely related to a geopolitics perspective. Basically, political leaders in many states mainly measure their own strategic outcomes in the new era surely from the view of the state's geopolitics, such as a global vision. Therefore, The strategic relationship among the major powers leads to upgrading regional integration.

Yet, here's the question that should be asked: What has been the political incentive of the special relationship between the Arabs states and China? In current years, the international system seems to be labeled as "a stable West through a weak East, and a stable North through a weak South. Basically, China and the Arab states are facing heavy pressure from Western states and are often named as "undemocratic states" or "authoritarian states", with weak human rights background". Both have been in a protective side for a period and hence have a common understanding with and mutual support for each other in international relations. The Chinese and the Arabs have ameliorated their political confidence and built up a strategic partnership, standing among quasialliance and comprehensive cooperation. therefore, this strategic partnership has less credibility on commitment than quasi-alliance, its benefits are also visible. In one hand, strategic partnership is in policy with the "Nonalignment" doctrine of China and the Arab states. It is a useful doctrine to independent foreign policy; "Nonalignment" doctrine does not alike strategic cooperation. By May 1984, Deng Xiaoping pointed out when he met with Brazilian President Figueiredo, then said: "China's foreign policy is independent and is positively non-alignment policy. China does not ally with the US, nor with the Soviet Union” (Deng, X., 1999: 57). Again, China had set up a strategic partnership with the United States to cut off the expansion of the Soviet. The rational formula of strategic cooperation is the use of foreign resources when sustaining diplomatic independence and flexibility.

On the other hand, strategic cooperation can secure the autonomy of diplomatic activities of both sides. The rational model of the alliance is to restrain and bound foreign policy options of allies by limiting the actor's own activities. It enhances the state's cost, but it can help stop the allies from using opportunistic manner, hence making it more deterministic manner. As a result, for both Arab states and Chinese, strategic cooperation is a significant diplomatic resource and benefit.

\section{The Reciprocal links: Arab -China Strategic Partnership}

The Sino-Arab strategic partnership can be seen generally through two different reciprocal links: one through bilateral links and the other in the multilateral sphere. First, there exist some Socio-cultural divergence among China and Arab states, although both states belong to an oriental society with the focus on collectivism, dignity, and family orientation. With the Arab states, political systems, community- religion- interactions and the degree 
of close relations with Western states also very diverse, which needs China to treat these states reciprocally when establishing a strategic partnership and to discover the mutual benefits in cooperation. From the outlook of bilateral relations, the main Arab states, like Saudi Arabia, Algeria, Egypt, and Sudan are regularly enhancing their two-sided cooperation with China. These states are of geopolitical typical in the Maghreb gulf region, Eastern Mediterranean and Northern Africa.

The strategic partnership between China and Saudi Arabia starts to change in recent years. Saudi Arabia is a major regional power in the Arab Gulf region, as well as a key actor country in the Arab Muslim world. It is one of the fundamental sponsors of the Arab Organization of Islamic Cooperation and acts actively in the Middle East and the Islamic Arab world. Saudi Arabia is also the head of the two holy sites of Mecca and Medina, so developing bilateral economic process, political and security interrelationship with Saudi Arabia will promote China's impact from the Gulf to the Red Sea. Additionally, Saudi Arabia is the main to China's energy security supplier. In the Arab Gulf region, Saudi Arabia is an essential oil producer and exporter so far. In recent years, with the fall of US imports from Saudi Arabia and more dependence on shale gas at home, there is an encouraging prospect of Sino-Saudi Arabian collaboration in oil. Experts and public opinion of Saudi Arabia are disappointed with the US policy of "neglect" since the Arab Spring uprisings in 2011; this has added a significant encouraging reason in the Sino-Saudi Arabia strategic partnership. The disagreement US-Saudi relations, "balance of power" strategy of Saudi Arabia in current years and the "Eastward" strategy generally give a good chance for a Sino-Saudi Arabia strategic relationship (Korany, B. Dessouki, A., 2008: 343-396). Last President Hu Jintao embarked to Saudi Arabia in 2006 and again in 2009, which highlights China's concern to its rational relationship with Saudi Arabia. Since Saudi Arabia moves at the gathering points of "Silk Road Economic Belt" and "the Maritime Silk Road of the 21st century", both sponsored by President Xi Jinping, China will surely enhance Sino-Saudi relations to a new high strategic level.

For instance, Algeria and Egypt are placed at the intersection of Asia and Africa, the Mediterranean and the Red Sea, as well as the East and the West. Their geopolitical position for Beijing's interest is the decisive states. In current years, Algeria and Egypt have been experiencing the crucial tasks of developing their economy and sustaining domestic stability; both sustain a strategic relationship with China, which shares mutual national interests. The United States had put coercion on the Mubarak and thereafter the Morsi governments as well as on the Algerian Abdelaziz Bouteflika administration, pushing them to pursue a Western ideology of democratization. This urged both states has no choice but to quest foreign support, like asking China to balance against Western powers (Kamrava, M., 2007: 177-202). Algeria and Egypt are not only Arab Maghreb states, but also African states. Thus, both states are important for both China-Arab relations and China-Africa relations.

In the end, in terms of the strategic cooperation and partnership among China and Sudan, China's act on South Sudan and the Darfur conflict has successfully shaped the frame for the development process of bilateral relations and mutual cooperation. Since a valuable resource of oil was found in Sudan in the 1990s, both states have started to set up a strategic partnership through energy and trade relations. Additionally, Sino- Sudanese cooperation and comprehensive policy in the energy sector had tied both states for deeper strategic cooperation. The strategic cooperation among China and Sudan, somehow, is the outcome of the influence of globalization on national security. From China's view, as Beijing's new concept is a comprehensive security approach, it requires that government leaders should not only concern the safety affairs of sovereignty, territorial integrity, and other issues in high politics, but also to consider the market, employment, stability and energy supply issues in low politics (Kirshner, J., 2006: 297). So, globalization has made it a duty for China's national security strategy to adhere and serve the entire circumstance of " reform and opening up" policy, modernization, and China's economic security.

Currently, Sudan actively enhances two-sided cooperation with Beijing in the political and economic arena, and advocates China on the issue of "human rights" and the "Taiwan issue", among others. China, in return, also uses its seat power in the United Nations Security Council to protect the sovereignty and territorial integrity of Sudan. For instance, the Beijing government stressed that the Darfur Conflict is fully an internal affair of Sudan. China suggested that rational solutions should be proposed through talks and consultation, opposing Western sanctions or coercive ways to intervene in Sudan's domestic affairs. It also pointed out the significance of an unbiased manner to convince Sudan's President Omar al-Bashir's government to compromise and provide a constructive way out to both northern and southern Sudan.

3. The Arab- China's Strategic partnership in Multilateral Framework

Additionally to reciprocal Links, China has pushed the strategic partnership with the 22 Arab members towards multilateralism strategy, like the Arab League, the Arab Maghreb Union, the GCC, the African Union, the UN, 
IMF, World Bank, and the G20. China has an accumulation of history concerning its benevolence relationship with the Arab world as a whole. On December 21, 1963, Zhou Enlai suggested some principles to cope with Arab states relations during his journey to Egypt. this visit has discussed several points: first, China backs the Arab cause to fight against imperialism, win and shield national independence; second, China helps the Arab states to seek peaceful and nonalignment policy; third, China advocates the Arab community to get national solidarity and unity in their own ways; fourth, China helps the Arab states to resolve their disputes through peaceful negotiation and diplomacy; fifth, the sovereignty of Arab states should be respected by all nations and China rejects any aggression or intervention against them (Communist Party Literature Research Center, Ministry of Foreign Affairs, 1990: 387). By1971, many Arab states, altogether with African states, voted in respect of regaining the People's Republic of China's seat in the United Nations Security Council. A the same time, China stood by the Arab states in all United Nations resolutions on the Palestinian Conflict. In term of multilateralism, as IR scholar ( Ruggie,1993,p.11) defined it: that multilateralism needs the following three features: indivisibility, generalized organizing principles, and diffuse reciprocity. So China will build up a closer multilateral strategic partnership with the GCC in the coming decade. In the beginning, both partners will advance the pace of building a free trade zone; China and the GCC will create a closer strategic interrelationship to enhance the flexibility of Arab states in foreign policy. China will enlarge its foreign outcomes in the Arab world and even throughout the Middle East via multilateral features of the Arab League, while it faces several obstacles but China keep supports the Arab League and hopes it would play a more effective role for the Middle East in international relations. China will also promote strategic cooperation with the GCC countries through the United Nations General Assembly, the U.N. Security Council, and other multilateral and regional organizations.

\section{Norms and obstacles In the framework of Strategic Partnership between China and the Arabs Countries}

In the framework of Strategic cooperation and partnership among China and the Arab states show several measures. The first is policy flexibility. China does not recognize friends and enemies due to their political systems, nor by how close a country is to other superpowers. Alternatively, China has been strongly developing its relations with any country as long as it can devote to China's national security and foreign interests in the current era. For instance, Saudi Arabia is an important security partner of the United States, but in recent years, the relationship between Saudi Arabia and China has made tremendous headway (Sun, D., 2008: 34-41). Secondly is to maintain a low profile. establishing a quasi-alliance with the Arab League partners may produce the suspicion of the United States, Europe, Russia, Iran, Turkey, and even Israel. More than that, currently it is not in China's long-term interests to certainly challenge the hegemony of Western states in the Middle East which is likely to provide a reason for hard times in the United States to further contain China, pushing China to possibly be caught in a "Clash of Civilizations" ambush. As a result, when building up the China-Arab strategic partnership, China has focused on the cooperation of share benefits, preventing any involving third party. The third, the note is to keep the strategic partnership at the low profile level. A strategic partnership among China and the Arab states is suitable with the "Dos and Don'ts" concept, and China's presence is largely confined to political cooperation, thus preventing being involved in the Middle East security disputes (Sun, D., and Zoubir, Y.: 2014: 2). After the Iraq invasion, the Arab states have been moved ahead to the disputes between the Islamic world and the West. The Obama administration has failed repeatedly to change US profile with the Arab and the Islamic world and to calm down pressure in US-Arab relations. Though conflicts between the Arab world and the West appeared to have eased after Obama addressed his Cairo speech in 2009 (New York Times, 2009: June 4), paradox and divergence in culture, morals, and opinions about the international system between Muslims and Westerners have maintained intact. As a result, the Arab states altogether are important to China in sense of their rich oil and gas resources and their significant geopolitics.

In the next decade, China and Arab states will also be facing a series of inevitable issues in establishing a solid strategic partnership, which will surely influence the roots of bilateral strategic cooperation. First, there are severe issues of discord within the Arab world. After the Middle East uprisings, Arab countries, which have different interests, national circumstances and political development status, hold different ideas on their respective external strategies. They become more sensitive on issues, like the Israeli war on Gaza, the Syrian civil war, the Iranian nuclear conflict, and some other major issues..., all of which have influenced badly the role of their bilateral strategic cooperation and partnership. Nowadays, the Shanghai Cooperation Organization (SCO) has become a global organization with a global impact. Besides, conferences are held within the framework of the China-Africa Cooperation Forum (FOCAC); but, the CASCF is still held only at the ministerial stage, which represents the divergence among the Arabs. Second, regional integration in the Arab world is somehow absent. Compared to Europe, North America, South America, Southeast Asia, and even Africa, the Arab states has a lower profile of integration, although its regional organizations were build up previously. So, the Arab Maghreb, the Arab League Union, and the GCC all have troubles in decision-making 
orientation and lack of performance. The Arab world, Turkey, Iran, and Israel have been at a low profile of regional integration, which will also influence its strategic cooperation and partnership with China in general. Finally, China and the Arab states' acts in each other's overall diplomacy is basically criticized. Concerning China's diplomacy, the grand strategy is defined as "considering great powers as the core, surrounding neighbors as the primary, developing states as the important and multilateral relations as the stage". China has seen the United States, Russia, Europe, East Asia, Southeast Asia, South Asia, and the Central Asian states as diplomatic superiorities; Unlike, the Arab world is still at a lower stage. For their part, some of the Arab states also seen their connection with the United States, the EU, surrounding states and the Islamic world as their first concern(Preference), particularly in the security sphere. described by the several member states of the Gulf Cooperation Council, main Arab states fully depend on Western powers to provide them with a security parapluie like: "peering West for the protective badge", while depending on Asian powers, for economic development such as China, India, Japan, and South Korea.

\section{Conclusion}

The China-Arab States strategic partnership is based on mutual trust and benevolence cooperation. Since 2004, highly appreciation to the sequence consolidated bilateral strategic partnership, economic and trade ties between China and Arab states have been developing regularly. The main goal of China's strategic cooperation and partnership with the Arab states is to sustain strategic flexibility and accordingly make circumstances upgrading. So far arrangements can be made by the decision-makers' evaluations of the trade exchange. Alliance politics Approach is a function of the US to quest and sustain its world hegemony; in contrast, the China-Arab states strategic partnership only works at creating a healthy atmosphere for economic and political bilateralism rather than subjecting third parties. In other words, this cooperation is not undertaken at the expense of other states' outcomes. Therefore, the strategic partnership is mainly to sustain China's and the Arab world's right to the development process. It also targets expanding China's independent foreign policy of peace process. In sense of usage of the strategic cooperation with the Arab states, China can make not only use of reciprocal links, but can also take benefit of the multilateralism like the Arab League, the UN, and the Arab Maghreb Union. Yet, As two great civilizations, China and Arabs are "shared Dream" under the so-called respective national rejuvenation in the 21 st century.

\section{References}

An, H. (2005: September). Strategic foundation for Sino-Arab Cooperation in the new century, Arab World Studies, No.5.

Gowa, J. (1995). Allies, Adversaries, and International Trade, Princeton: Princeton University Press.

Li, W. (2005: November). Relations between Chinese and the Arab countries in a New international environment, Arab World Studies,

Sun, D. \& Zoubir, Y. (2014: January). China's response to the revolts in the Arab world: A case of pragmatic diplomacy, Mediterranean Politics, Vol. 19, No. 1. Text: Obama's speech in Cairo (2009: June 4). New York Times.

Xi, J. (2014: June 6). Carry forward the spirit of the silk road, deepen China-Arab cooperation, Wen Wei Po.

Gill, B. (2007). Rising Star: China's New Security Diplomacy, Washington D.C.: Brookings Institution Press.

" China's Participation in the Middle East Peace Process Welcomed: Egyptian Assistant FM," The People's Daily, November 23, 2004.

Shanghai Social Sciences Association (2006). The harmonious world, Shanghai: Shanghai People's Publishing House.

" China's Oil and Gas Import Strategies to 2020, " Global Energy and Utilities Market Research, Washington, DC, April,2001.

Rosenau, J. \& Thompson, K. \& Boyd, G. (1976). World Politics, New York: Free Press.

"Iran Seeks to Join Shanghai Cooperation Organization," Tehran Times www.techerantimes.com, September 7, 2008.

Li, W. (2012). Middle East political transition and China's diplomacy in the Middle East, West Asia, and Africa, No.4.

Huang, C. (2013). Theory of China's participation in global governance, Journal of International Relations, No.4.

Wang, H. \& Rosenau, J. (2009). China and global governance, Asian Perspective, Vol.33, No.3.

Degang SUN \& Yahia ZOUBIR (2014) China-Arab States Strategic Partnership: Myth or Reality?, Journal of Middle Eastern and Islamic Studies (in Asia), 8:3, 70-101, DOI: 10.1080/19370679.2014.12023246

Wallensteen, P. (2007). The Crisis of Governance in the Middle East: Understanding Conflict Resolution, London: Sage Publications Ltd.

Wu, L. (2014). The construction of the new Silk Road: new meaning of development of relations between China and the Middle East, West Asia and Africa, No.3. 
Shannon Tiezzi, “The New, Improved Shanghai Cooperation Organization”, The Diplomat,13 September 2014 at :

http://thediplomat.com/2014/09/the-new-improvedshanghai-cooperation-organization/ (last visited 13 March 2016).

Wang Dong, "Is China trying to Push the U.S. out of East Asia?", China Quarterly of International and Strategic Studies, Vol. 1, No. 1 (2015), p. 70.

Ruggie, J. G. (Ed.). (1993). Multilateralism Matters: The theory and praxis on an international form. New York: Columbia University Press. 